\title{
REGIONÁLIS KÜLÖNBSÉGEK AZ EMBERI ERŐFORRÁS MENEDZSELÉS GYAKORLATÁBAN ${ }^{1}$
}

(Regional Differences in Practice of Management of Human

Resources)

\section{FARKAS FERENC - KAROLINY MÁRTONNÉ - POÓR JÓZSEF}

\section{Kulcsszavak:}

emberi eróforrás menedzselés konvergencia divergencia CRANET-kutatás

Amikor a vezetỏ európai emberi eróforrás menedzsment kutatók az elmélet és gyakorlat európai sajátosságait vizsgálták, egészen a közelmúltig megfeledkeztek Közép- és Kelet-Európáról. A Cranfield University koordinálásával folyó CRANET-kutatás lehetövé teszi ennek a hiánynak a pótlását; a magyar részvétel pedig a hazai sajátosságok elemzését az európai gyakorlathoz viszonyitva. A tanulmány a régiók szerinti hasonlóságok és a különbségek (konvergenciák és divergenciák) meglétét kutatja nagyminták felhasználásával, és a kapott eredményeket egybeveti korábbi magyarországi és európai kutatások megállapitásaival.

A termelỏ és szolgáltató vállalatok világméretú globalizálódása az elmúlt évtizedekben alapvető változásokat hozott az emberi erőforrásokkal kapcsolatos gazdaságtani és menedzsment megközelítésekben és módszertanban. Az emberi erőforrás gazdaságtana és menedzsmentje az élessé váló nemzetközi környezetben a versenyelöny megteremtésének egyik kulcstényezője lett (Sparrow-Hiltrop 1994), miközben a tanulmány fókuszában álló emberi erőforrás menedzsment (a magyarban az EEM, angolban a HRM rövidítés az elfogadott), folyamatosan vívja harcát a saját legitimációjáért, ahogyan azt Szöts-Kovács Klaudia kitúnỏ írásában (2006), egy negyven évvel ezelötti publikációból idézi: „a személyzeti szakértők csoportjảnak történelme egyenló a vezetői csapat teljes értékủ tagjának státusáért vívott küzdelemmel." (Antony-Crichton 1969, 165) Mindeközben megjelentek a szignifikáns eröfeszítések (Schuler-Dowling Cieri 1993) a stratégiai nemzetközi emberi erőforrás menedzsment integratív keretének kidolgozására. Ez a megközelítés azóta is a HRM és a stratégia összefüggéseit kutatja nemzetközi szintéren, több-kevesebb sikerrel.

E tanulmány szerzői jó egy évtizede kezdték meg kutatómunkájuk eredményeit összefoglaló publikációk közlését (Elbert-Karoliny-Farkas-Poór 1994). Később a fókusz folyamatosan a stratégiai jellegre és nemzetköziesedésre helyeződött - követve egyrészt az adott terület tudományában megfigyelhetō, egyik meghatározó vonulatot; másrészt a nemzetközi vállalatok magyarországi terjedése által kiváltott igényeket (Poór 1996; 2006; Poór-Farkas 2001). 
Tér és Társadalom 22. évf. 2008/2. 103-122. p.

Korábbi nagymintás vállalati kutatásaink (Karoliny-Csetneki-Poór-Spisák 2000) a különböző méretú-, profilú-, tulajdonosú stb. szervezetek emberi eröforrás menedzselési sajátosságait kívánták feltárni. Fontos megállapításra jutottunk az emberi erőforrás rendszerek kialakításának befolyásoló tényezöiröl, az emberi erőforrás menedzselési funkciók müködéséről, az alkalmazott módszerekröl, a személyi tényezőkröl és más elemekröl. Tapasztalatokat szereztünk az összehasonlító jellegü vizsgálatok módszertanának alkalmazásáról, bár ez idö tájt még csak országon belül, szervezetek közötti szinten.

Ezalatt a nemzetközi emberi erőforrás menedzsment alkalmazások vizsgálatában az összehasonlító kutatások térhódítása nyomán mértékadó, ủj eredmények születtek (Budhwar-Sparrow 2002). Ezek az összehasonlító kutatások jellemzỏen a következö kérdésekre keresik a választ:

- Milyen a HRM szerkezete az egyes országokban?

- Mely stratégiák alkalmazása a legjellemzőbb?

- A stratégiákból mit ültetnek át a gyakorlatba?

- Mik a hasonlóságok és a különbségek az alkalmazásokban?

- Milyen befolyásoló hatással bírnák az olyan tényezők, mint pl. a kultúra, a kormányzati politikák és az oktatási rendszer?

Ilyen kérdésekre a korai válasz Jackson és Schuler (1995), valamint Locke és Thelen (1995) nyomán úgy adható meg, hogy a tényezők befolyásoló hatásának mértéke és iránya környezetfüggö és - ha nem is országról-országra, de - régiórólrégióra változik. A változások jellegének és mélységeinek vizsgálata napjainkra az emberi erőforrásokkal foglalkozó kutatások legfontosabb kérdésévé vált.

\section{Konvergencia, változatlanság vagy divergencia?}

A szervezeti határokon túlmutató vizsgálatok a régiók és az országok humánerőforrás-megközelítés gyakorlatai közötti hasonlóságokat és különbözöségeket igyekeznek feltárni. Ezek sorában kiemelkedö az a kutatás (Mayrhofer-MorleyBrewster 2004), amely 18 európai országra kiterjedően az 1990-1999 közötti évtized fejleményeire, változásaira irányult. Igazolni próbálta azt a korábbi megállapítást, miszerint: ha létezik konvergencia, (összetartó hasonlóság) akkor annak két különböző iránya van: a szabadpiaci amerikai modell és az intézményi európai modell által leírható konvergenciák. További, lényeges hasonlóság: a vállalatok hatáskörét tekintve mind úgy látják, hogy azok különböző technológiai, gazdasági és intézményi tényezőkkel próbálják a személyzetfejlesztési stratégiákat formálni és megvalósítani (Gooderham et al 2004).

$\mathrm{Az}$ idézett kutatók megállapításai szerint három, alapjaiban különböző irány vezethetö le:

1) A piaci erők konvergenciát generálnak az európai cégek HR gyakorlatától az amerikai modell felé. 
Farkas Ferenc - Karoliny Mártonné - Poór József :

Regionális különbségek az emberi erőforrás menedzselés gyakorlatában.

Tér és Társadalom 22. évf. 2008/2. 103-122. p.

TÉT XXII. évf. 2008 - 2

Gyors ténykép

2) Az összeurópai intézményi erők konvergenciát generálnak az európai cégek HR gyakorlatától egy közös európai modell felé, amely lényegében különbözik az amerikai gyakorlattól.

3) Az alapokig (a meghatározó szervezeti jellemzőkig) visszavezethetô eltérés az európai országok között divergenciákhoz vezet - de legalábbis nem vezet konvergenciákhoz - az európai cégek HR gyakorlatát illetően.

A kilencvenes évtized változásait elemző vizsgálat végül is a konvergenciának két formáját különböztette meg: az irány-konvergenciát és a vég-konvergenciát.

Irány-konvergencia: amikor a vizsgált országok közötti fejlődés egy közös pont irányába halad. Vég-konvergencia: amikor a vizsgált országok közötti fejlődés egy közös pontban végződik. Mayrhofer egy újkeletủ írásában (Mayrhofer-Reichel 2006) a konvergencia jelentésének pontosítására kialakított egy harmadik értelmezést is. Ez a többségi konvergencia, amikor hasonlóak (50\% körüli megoszlással) a fejlemények. Ezek az eredmények azonban lényeges következtetések levonására nem adnak alkalmat, további vizsgálatokra van szükség.

A konvergencia-divergencia fogalomkörnek a személyzeti közgazdaságtan által használt értelmezése szerint akkor beszélhetünk az eljárások és alkalmazások (megoldások) konvergenciájáról egy ország vagy országok csoportjának vállalatai körében, ha az alkalmazások költségeinek és hasznainak viszonya hasonló módon alakul. A konvergencia-divergencia ilyen irányú létezésére irányuló vizsgálatokat nagyban nehezíti az a tény, hogy az elemzések többnyire megállnak a „mi van” jellegü pozitív gazdaságtannak nevezett elemzéseknél, és ritkábban jutnak el a „minek kellene lenni" típusú, a normativ gazdaságtan elemzési metodikájához (Ehrenberg-Smith 2003, 21). A munka (és a szervezetek) világában végbemenó változások erỏteljesen befolyásoltak a társadalompolitika, a kormányzati politika, a munkaerőpiac és más tényezők hatásai által. Ezek a tényezők közismerten országonként jelentős eltérést mutatnak, még például az azonos európai uniós irányelvek ellenére is. Így a befektetés/hozam viszony alakulása a szervezet által függetlennek tekintett változók jelenléte miatt igen nehezen elemezhetö, különösképpen nehezen számszerúsíthetö. Véleményünk szerint ez a konvergencia kutatások második szintjét jelentené, amikor a hasonló-különböző (összetartó-széttartó) jellegú alkalmazások a vizsgált szegmensekben hasonló, vagy éppen különbözó elmozdulást hoznának a költség/haszon relációkban. Az ilyen típusú vizsgálatok, adatok hiányáról ír Edward Lazear, az NBER (National Bureau of Economic Research) Working Group igazgatójaként (Lazear 2003). Tíz országból nyert adatok nem voltak elégségesek a várható vállalati viselkedések leírására (pl. a vállalati bérstruktúrák átalakításakor), ezért az alkalmazások körülményeit esettanulmányok felvételével kellett megvilágítania a kutatóknak.

A HRM konvergenciák és divergenciákkal kapcsolatos saját kutatási eredményeink megértéséhez szükségesnek tartjuk Mayrhofer és társai által megfogalmazott feltevések és eredmények rövid bemutatását (Gooderham-Morley-Brewster-Mayrhofer 2004). 
a) Statisztikailag szignifikáns a változás, és beigazolódtak a feltevések a következőkben:

1) $\mathrm{Az}$ elmúlt évtized során csökkent az európai vállalatok HR részlegeinek relatív nagysága.

2) Az elmúlt évtized sorản az európai vállalatoknál nőtt a képzésre fordított összegek személyzeti összköltségen belüli részaránya

3) Az elmúlt évtized során nőtt azoknak a vállalatoknak az aránya Európában, amelyek alkalmazotti részvényopciókat, nyereség-részesedést, csoportbónuszt vagy teljesítményalapú javadalmazást kínálnak a dolgozóknak.

4) Az elmúlt évtized során az európai vállalatoknál nőtt azoknak az alkalmazottaknak az aránya, akik tájékoztatást kapnak a vállalati stratégiát és a pénzügyi helyzetet illetően.

b) Nem szignifikáns statisztikailag, de mutat változást ebbe az irányba az a tapasztalat, hogy az elmúlt évtized során nőtt azoknak az európai vállalatoknak a száma, amelyek rugalmas foglalkoztatási, munkaszervezési gyakorlatokat alkalmaznak, mint pl. távmunka, outsourcing.

c) Eltérések mutatkoznak az egyes országok között:

1) Az elmúlt évtized során nőtt azoknak a vállalatoknak az aránya, amelyek a HR politikát leányvállalati vagy telephelyi szintre delegálják, kihelyezik.

2) Az elmúlt évtized során nött azoknak a vállalatoknak az aránya, amelyek a HR feladatokat és felelősséget a HR szakemberektől egyre inkább a szakmai vezetéshez telepítik.

És a vég-konvergenciára nézve az idézett kutatásban nem igazolódott a feltevés, ellenkezöleg: az európai országok HR gyakorlatában a kilencvenes évtized közepén több, a konvergenciára utaló jelet lehetett tapasztalni, mint az évtized végén.

\section{A Cranfield Network}

A Cranfield Network (CRANET) (az angliai Cranfield Business School által alapított és mủködtetett Európai Emberi Eröforrás Kutatási Hálózat) projekt eredményei, a problémák felismerése és az azokra időközben született megállapítások alapján járul hozzá a nemzetközi HRM fejlödéséhez. Mindig is nagy vállalkozás volt változatos társadalmi-gazdasági és kulturális környezetben összehasonlító adatokat gyüjteni a szervezetek HRM gyakorlatáról.

$\mathrm{Az}$ elmúlt évek során az emberek vezetése a különböző nemzeti környezetben múködő szervezetekben a stratégiaalkotók és a szakszervezetek számára egyaránt egyre fontosabbá vált. A nemzetközi szervezetek terjedése, a nemzetközi munkaerőpiac és az egységes európai piac kialakulása csak néhány azok közül a körülmények közül, amelyek következtében egyre nagyobb az igény a konvergencia és a divergencia területeinek megértésére szervezeti szinten, a vezetöi gyakorlatban. Az információk, az elemzések és a következtetések fontosak lennének a munkaeröpiac érdekhordozói számára. 
Mindezek ellenére bár növekvő mennyiségủ, de mégis korlátozott számú összehasonlítható, empirikus információ áll rendelkezésükre. Azok az elérhető adatok, amelyek olyan szervezetektöl származnak, mint az Európai Bizottság, a Nemzetközi Munkaügyi Szervezet, a Gazdasági Együttmüködési és Fejlesztési Szervezet a makromunkaerö-piaci nézőpontra koncentrálnak. Ez fejezi ki a stratégiai érdekhordozók elsődleges érdekeit. Azonban ma is korlátozott azoknak az eredményeknek a száma, amelyek a vezetési gyakorlatra világítanak rá, hasonlóan nagy léptékủ összehasonlitásokat végezve ágazatokon, országokon, közép- és nagyvállalatok széles körén keresztül. A CRANET-projekt elsődleges célja, ezt a hiányt pótolni, az Egyesült Királyságbeli Cranfield Egyetem Üzleti Karának irányításával (Tregasikis et al 2004).

A nemzetközi kutatásban jellemzően két uralkodó módszertant alkalmaznak: az esettanulmányt és az összehasonlító felmérést.

$\mathrm{Az}$ esettanulmány erőssége a rugalmassága, az, hogy képes alkalmazkodni a különbözỏ nemzeti környezethez, képes feltárni az összetett környezet hatását és az egyedi jellemvonásokat. Az esettanulmány az előzetes adatgyüjtést megelőzően nem követel pontos, elméleti és fogalomtisztázást, erre a pontosításra a kutatási folyamat során is lehetöség van.

Az összehasonlitó felmérés célja, hogy megtalálja és azonosítsa a jelentőséggel bíró jelenségeket. A CRANET-projekt ez utóbbi megközelítést választotta. A felmérés témakörei: a személyzeti részlegek és a HR stratégia, toborzási politikák, fizetés és juttatás, képzés és értékelés, a foglalkoztatási formák és a rugalmas munkaidő, a munkaügyi kapcsolatok és alkalmazotti kommunikáció. A nemzetközi összehasonlító felmérés kritikus erőforrása a kutatócsoport, ugyanis ők értelmezik az adatokat (Brewster et al 2006).

A Pécsi Tudományegyetem Közgazdaságtudományi Karának Vezetési és Szervezési Tanszéke 2004-ben ilyen kritikus erőforrás részévé vált azzal, hogy bekerült a nemzetkőzi kutatócsoportba. A jelentkezést elfogadó döntés mögött -észben a korábban hivatkozott szakirodalmi referenciák mellett további, a kutatás tárgyához illeszkedö újabb empirikus vizsgálataink álltak.

- 2002-ben 112 cég részvételével vizsgáltuk a Magyarországon müködő cégeknél a személyzetbiztosítási, foglalkoztatási és emberi eróforrás menedzselési gyakorlat magyarországi helyzetét (Farkas-Karoliny-László 2003a; 2003b).

- 2004-ben 27 cég részvételével azt vizsgáltuk, hogy az EU-csatlakozás milyen módon érintette a személyzetbiztosítást és az emberi erőforrás menedzselést (Poór-Tódor 2004).

- 2004-ben 42, Magyarországon megtelepült multinacionális vállalat (MNV) leányvállalatainak személyzetbiztosítás, foglalkoztatási és az emberi erőforrás menedzseléshez kapcsolódó gyakorlati alkalmazásait, valamint mindezek történeti fejlődését vizsgáltuk az életciklus modell alapján. Arra kerestük a választ, hogy ezek a funkciók és a gyakorlati alkalmazások hogyan is alakultak az elmúlt 15 év rohanó gazdasági változásai közepette (Poór 2005; 2006). Ez 
a vizsgálat folytatódott 2007-ben az Országos Foglalkoztatási Alap által finanszírozott szervezeti életciklus kutatásban.

- 2005-ben a Dél-dunántủli régióban 112 hazai KKV-nál vizsgáltuk az életciklus modell függvényében a müködés, a menedzselés, a személyzetbiztosítás és az emberi erőforrás menedzselés helyzetét. $\mathrm{E}$ kutatás három időszakot ölelt fel: a vállalkozások megalakulásának időszakát, a megerösödési időszakot, és az EU csatlakozás utáni helyzetet (Poór-Gross-Javalgi 1998; Kiss et al 2006; Kiss-Poór 2006).

- A 2005-ös CRANET-kutatás magyarországi és kelet-európai sajátosságainak elsö eredményeiröl nemzetközi konferencián számoltunk be az Amerikai Egyesült Államokban (Poór et al 2007).

Fontos kiemelni azt a tényt, hogy amikor az ismert európai HRM kutatók, szerzök (Sparow-Hiltrop 1998; Brewster et al 2004; Evans et al 2002) az európai HRM sajátosságait vizsgálták, akkor ezidáig a nyugat-európai gyakorlat jellegzetességei alapján tették ezt. A kelet-közép-európai HRM önálló csoportként való tárgyalását mára éppen a CRANET-kutatások terjedése tette lehetővé. A korábbi években (1992, 1998, 2003) elvégzett CRANET-kutatások nyomán számos publikáció jelent meg a régió egyes országainak HR gyakorlatáról. Ide sorolhatók, a teljesség igénye nélkül a bolgár Vatchkova (2005), Vatchkova et al. (2006) a cseh Koubek, illetve Vatchkova (2005) és az észt-szlovén szerzőpáros Alas-Svetlik (2004) tollából megjelent írások.

\section{$A$ vizsgálat tartalma és résztvevöi}

A kutatás alapjául szolgáló egységes CRANET kérdőív mintegy hatvan kérdésből áll, melyek a következő részterületeket érintik:

- Az első rész a felmérésben részt vevő szervezetek emberi eröforrás (HR) menedzselésének és szakembereinek/részlegeinek szervezeti hierarchiában elfoglalt helyét, szerepét vizsgálja.

- A kérdőiv második része a személyzetbiztositás gyakorlatára kérdez rá.

- A harmadik rész a teljesitményértékelés, személyzetfejlesztés, karrierfejlesztés területeire vonatkozó kérdéseket tartalmazza.

- A negyedik rész az ösztönzés-juttatás használt módszereit kutatja.

- Az ötödik részében a szervezeten belüli munkavállalói kapcsolatok, dolgozói kommunikáció létére, illetve formáira keres választ a kérdőív.

- A hatodik rész a szervezeti jellemzőkre vonatkozó kérdések megválaszolásának a helye.

- A hetedik részben pedig a kérdőívet kitöltö szervezet és személy föbb azonosítóit kérik megjelölni.

A kérdőív statisztikai elemzésének megkönnyítése érdekében a CRANET-kutatás zárt kérdéseket alkalmaz, a vizsgált témaköröket nagymértékben lefedö, előre megfogalmazott válaszok közül a legjellemzőbbek megjelölését kéri a válaszadóktól. 
Emellett azonban minden esetben lehetőséget biztosít a megadott lehetőségeken kívüli, egyéb válaszok kifejtésére is. A kérdőivek válaszainak feldolgozása az SPSS szoftverrel történt.

A CRANET 2005-ös adatbázisába tehát a fentiekben jellemzett azonos kérdőívek használatával 32 országból - közte ez évben először Magyarországról is - érkeztek adatok, vélemények a szervezetek személyzetbiztosítási, foglalkoztatási és emberi erőforrás menedzselési jellemzöiröl. A teljes nemzetközi minta elemszáma 7952, melyből 864 kelet-európai, benne 97 magyar vállalkozás adataival. A magyar minta a Top 100, a nemzetközi vállalatok, a Magyar Kereskedelmi Kamara és az önkormányzatok címlistáiból véletlenszerủen kiválasztott 1100 szervezet kérdőív kitöltőiből formálódott. A kitöltött kérdőívek visszaérkezése megközelíti a 10\%-ot.

Az 1. ábrản szemléltetettek szerint elemzéseink középpontjában a 97 magyar vállalat és intézmény áll. Elsődleges viszonyitási alapul a teljes kelet-közép-európai minta szolgál, benne 6 ország (mintabeli szervezeteik számát lásd zárójelben) Bulgária (157), Csehország (72), Észtország (118), Magyarország (97), Szlovákia (259) és Szlovénia (161) - összesen 864 vállalatával és intézményével.

\section{1. ÁBRA}

Az elemzés részhalmazai és fókuszai

((Regional Differences in Practice of Management of Human Resources))

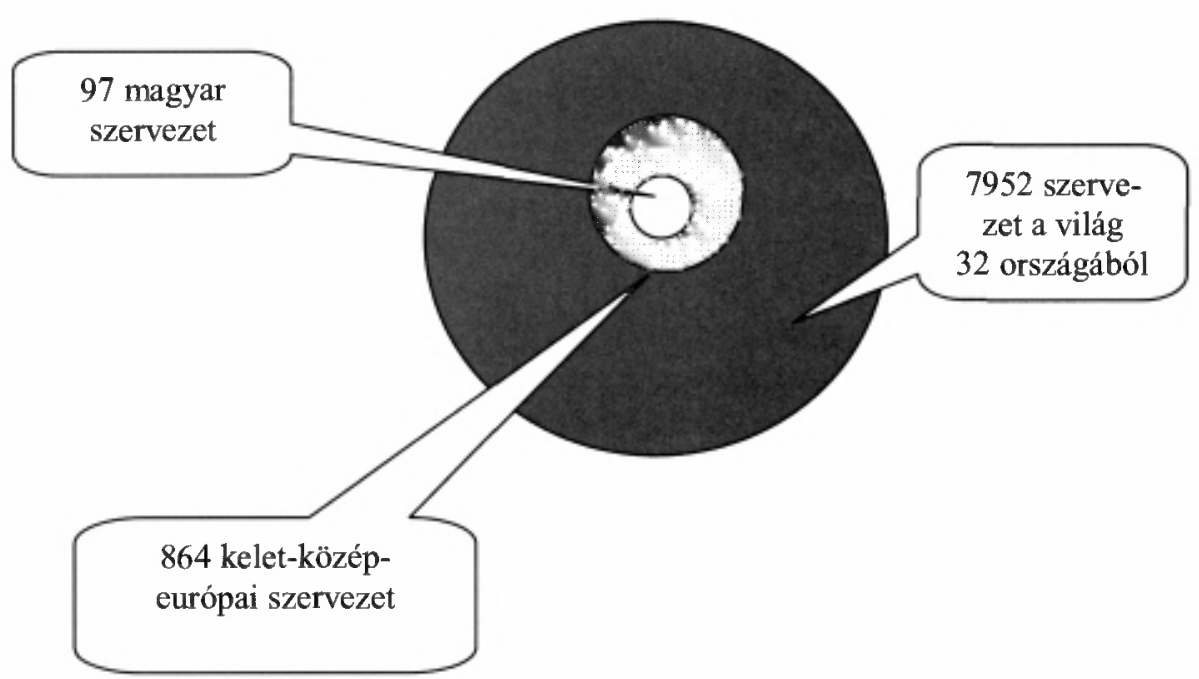

Forrás: CRANET-kutatás (2005).

A teljes résztvevői kört 32 ország - köztük jó néhány Európán kívüli - 7952 vállalata és intézménye alkotja. A legtöbb európai reprezentáns az Egyesült Királyságot (1101), Dániát (516), Hollandiát (397), Svéd- (383) és Németországot (347), valamint Svájcot (311) és Norvégiát (303) képviseli. Az Európán kívüli országok közül a legtöbb szervezet Kanadából (456), Új-Zélandról (286) és az USA-ból 
Tér és Társadalom 22. évf. 2008/2. 103-122. p,

(260), valamint Ausztráliából (259) küldött kitöltött kérdőívet. A többi, még nem említett részt vevő ország (és a felmérésben szereplö szervezeteinek száma) a következő: Finnország (293), Ausztria (270), Belgium (230), Nepál (204), Tunézia (189), Görögország (180), Izrael (175), Törökország (171), Spanyolország (158), Franciaország (140), Olaszország (117), Izland (114), Török Ciprus (87), Ciprus (85) és a Fülöp-szigetek (56).

\section{A vizsgált három minta alapjellemzői}

A magyar, a kelet-európai és a teljes minta szervezetei HR-jellemzőinek elemzése elött azok ágazat és szervezeti méret szerinti hasonlóságait és különbözőségeit vázoljuk, és bemutatjuk a csupán a magyar mintában vizsgált néhány jellegzetességet.

A kutatásban részt vevő szervezetek ágazati megoszlását illetően megállapítható (1. táblázat), hogy míg a teljes mintában a szolgáltatási szektor cégei alkotják az adatbázis majd felét, addig a magyar és még inkább a kelet-európai cégek esetében az ipar, építöipar szervezetei a dominánsak (46,2 ill. 52,6\% részaránnyal). A keleteurópai mintában - és benne a magyarban is -, a szolgáltató vállalatok részaránya alig éri el a $40 \%$-ot. Míg a teljes és a kelet-európai mintában a 2\%-ot alig meghaladó részesedéssel ugyan, de szerepelnek agrárszervezetek, ezen ágazat reprezentánsai a magyar mintában nincsenek jelen.

\section{TÁBLÁZAT}

A magyar, a kelet-európai és a teljes kutatásban részt vevö összes ország mintabeli szervezeteinek megoszlása (\%)

(Breakdown of Sample Organisations of All Countries Participating in Hungarian, East European and the Whole Research (\%])

\begin{tabular}{|c|c|c|c|c|c|c|c|}
\hline \multirow{2}{*}{ Ágazatok } & \multicolumn{3}{|c|}{ Ország(ok) } & \multirow{2}{*}{$\begin{array}{l}\text { Alkalma- } \\
\text { zotti lét- } \\
\text { szám (fó) }\end{array}$} & \multicolumn{3}{|c|}{ Ország(ok) } \\
\hline & magyar & $\begin{array}{l}\text { kelet- } \\
\text { európai }\end{array}$ & összes & & $\begin{array}{l}\text { ma- } \\
\text { gyar }\end{array}$ & $\begin{array}{c}\text { kelet- } \\
\text { európai }\end{array}$ & $\begin{array}{l}\text { ösz- } \\
\text { szes }\end{array}$ \\
\hline $\begin{array}{l}\text { Mezỏgaz- } \\
\text { daság }\end{array}$ & 0,0 & 2,2 & 2,1 & -250 & 38,5 & 41,6 & 33,4 \\
\hline Ipar & 46,2 & 52,6 & 38,8 & $\begin{array}{l}251- \\
1000\end{array}$ & 34,4 & 43,0 & 43,0 \\
\hline $\begin{array}{l}\text { Szolgálta- } \\
\text { tás }\end{array}$ & 39,8 & 39,7 & 48,0 & $\begin{array}{c}1001- \\
5000\end{array}$ & 20,8 & 13,3 & 17,3 \\
\hline Egyéb & 14,0 & 5,5 & 11,1 & $5001-$ & 6,3 & 2,1 & 6,3 \\
\hline Összesen & 100,0 & 100,0 & 100,0 & Összesen & 100,0 & 100,0 & 100,0 \\
\hline
\end{tabular}

Forrás: CRANET-kutatás (2005).

Ahogy az az 1. táblázat második szegmensének adataiból látható, a szervezeti méretet illetően a teljes minta résztvevőinek több mint kétharmada $(66,6 \%) 250$ fónél 
Farkas Ferenc - Karoliny Mártonné - Poór József :

Regionális különbségek az emberi erőforrás menedzselés gyakorlatában.

Tér és Társadalom 22. évf. 2008/2. 103-122. p.

TÉT XXII. évf. 2008 = 2

Gyors ténykép

111

több alkalmazottat foglalkoztató nagyvállalat. A szervezetek meghatározó többsége (43\%) ugyan e csoport legkisebb (251-1000 fö) méretkategóriájában található, majd negyedükröl mégis állítható, hogy a kifejezetten nagy létszámú (1000, sőt 5000 fölötti foglalkoztatottal müködő) cégek körébe tartozik. A válaszadó szervezetek dolgozóinak átlaglétszáma 1878,9 fỏ.

A CRANET sztenderd kérdésein túl, a magyar felmérésben a tulajdonosok kilétét is vizsgáltuk. A válaszok szerint a hazai és külföldi tulajdonú szervezetek mintabeli képviselete majd azonos arányú: 49,5 és $50,5 \%$.

\section{Vizsgálati eredmények}

1) A HR tevékenység szervezeti jelentőségét jelzö fontos mutató a bérköltségek szervezeti összköltségen belüli aránya, azaz a bér-költséghányad. Ez olyan alapvető mutató, amely nemcsak a bérszínvonalak eltérésére, hanem a müködés eröforrás-felhasználási struktúrájának különbözőségére enged következtetni. A magyar cégek mutatóinak átlaga $28 \%$ volt. E jellemző hasonlóképpen alakult a többi kelet-közép-európai szervezetnél is. A 32 ország adatait vizsgálva azonban megállapítható, hogy jó néhány olyan - magasabb bérszínvonalú - ország (pl. Hollandia) található, amelynek mintabeli szervezeteinél a magyamál és a kelet-európainál jóval magasabb (64\%) átlag-személyzeti költséghányad mutatók is elöfordulnak.

\section{TÁBLÁZAT}

A bér-költséghányad és eredményesség összefüggései a magyar, a kelet-európai és a teljes felmérésben részt vevö szervezeteknél

(Context of the Labour-Cost Ratio and Efficiency within Organisations Participating in Hungarian, East European and the Whole Survey)

\begin{tabular}{lccc}
\hline & \multicolumn{3}{c}{$\begin{array}{c}\text { A bérköltségek összköltségen } \\
\text { belüli aránya (\%) }\end{array}$} \\
\cline { 2 - 4 } Eredményesség: az árbevétel & $\begin{array}{c}\text { a kelet- } \\
\text { európai } \\
\text { országok- } \\
\text { ban }\end{array}$ & $\begin{array}{c}\text { Magyässzes } \\
\text { országon } \\
\text { országban }\end{array}$ \\
\hline $\begin{array}{l}\text { jóval meghaladja a költségeket. } \\
\text { elegendő egy kis profit képzésére. } \\
\text { elég a költségek fedezésére. }\end{array}$ & 28 & 22 & 35 \\
nem elég a költségek fedezésére. & 38 & 22 & 37 \\
alacsony és nagy a veszteség. & 68 & 30 & 46 \\
& 44 & 38 & 45 \\
\hline Mintaátlag & 28 & 24 & 38 \\
\hline
\end{tabular}

Forrás: CRANET-kutatás (2005). 
A bérköltség-hányad elemzésekor, annak szervezeti eredményességgel való kapcsolatát vizsgálva, a magyar és a világmintában egyaránt megragadható öszszefüggésre bukkantunk. Eszerint a magasabb bérköltség-hányaddal müködő szervezetek jellemzöen alacsonyabb eredményességüek (2. táblázat).

Érdekes összefüggésre utal, hogy a kelet-európai mintában a vizsgált kapcsolat F próbája már nem szignifikáns. Ez arra hívja fel a figyelmet, hogy az eredményesség és a bérköltség-hányad között máshol megragadott kapcsolatnak feltételezhetően van egy küszöbértéke. Amíg a teljes kelet-európai minta szervezeteinek átlagosan 24\%-os személyzeti költséghányada e küszöb alatti lehet, addig a magyar érték (28\%) éppen, a világminta 38\%-os szintje pedig jócskán átlépheti azt.

2) Arra a kérdésre vonatkozó válaszokkal, hogy „Kik, milyen mértékben befolyásolják az emberi eröforrás menedzselés terén hozott döntéseket?" a humán eröforrások közgazdaságtanának lényegéhez jutunk el. „A humán erőforrások kulcsfontossági ügyeit a vezérigazgatók döntik el, nem pedig a személyzeti szakemberek.... A vállalati munkaeröt érintő föbb döntések kezdeményezése a humánerőforrás-osztályon kívülröl jön." (Lazear 2006, 21) A megosztott felelösség érvényesülésének elemzése a CRANET-kutatásnak is része. A teljes minta egészére nézve a tendenciák a 3. táblázatban foglaltak szerint ismerhetök fel.

3. TÁBLÁZAT A HR politikák döntéshozói

$A$ vezetés és a HR felelösségterületei (a teljes mintán)

(HR's Decison Makers

(Areas of Responsibility of Management and HR [based on total sample])

\begin{tabular}{ccccc}
\hline \multirow{3}{*}{ HR területek } & \multicolumn{4}{c}{ A megosztott felelösség érvényesülése } \\
\cline { 2 - 5 } & $\begin{array}{c}\text { HR dön- } \\
\text { tés }\end{array}$ & $\begin{array}{c}\text { HR döntés a } \\
\text { vezetéssel } \\
\text { konzultálva }\end{array}$ & $\begin{array}{c}\text { Vezetói dön- } \\
\text { tés a HR-rel } \\
\text { konzultálva }\end{array}$ & $\begin{array}{l}\text { Vezetói } \\
\text { döntés }\end{array}$ \\
\hline
\end{tabular}

Toborzás-

kiválasztás

Létszámváltozás

Képzés-fejlesztés

Bér és juttatások

Munkaügyi

kapcsolatok

Forrás: CRANET-kutatás (2005). 
Farkas Ferenc - Karoliny Mártonné - Poór József :

Regionális különbségek az emberi erőforrás menedzselés gyakorlatában.

Tér és Társadalom 22. évf. 2008/2. 103-122. p.

TÉT XXII. évf. 2008 - 2

Gyors ténykép

113

Empirikus kutatásunk eredményei a kérdöívekben kapott válaszok alapján a következőképpen támasztják alá mindezt:

- A HR vizsgált területein a legjellemzőbb gyakorlat a megosztott felelösség. Ugyanis a vezetők vagy a HR szakemberek dominanciájával, de a másik féllel folytatott konzultáció alapján meghozott döntések majd minden kérdezett HR területen, mindegyik vizsgált mintában meghaladják az 50\%-os részarányt, az esetek többségében pedig a 70\%-ot is.

- A másik féllel folytatott együttmüködés, a konzultációra alapozott döntés legjellemzöbb területei: a toborzás-kiválasztás és a szervezeti létszámváltoztatás. Az elöbbi területen a közös döntés aránya mindhárom mintában meghaladja a 70\%-ot, míg a létszám-változtatási döntések kapcsán ez csak a kelet-európai mintában marad $70 \%$ alatt.

- Az egyuittmüködésre legkevésbé alapozó döntési terület a munkaügyi kapcsolatoké, ezt jelölték ugyanis a válaszadók mindhárom mintában csupán $50 \%$ körüli arányúnak.

- A vezetók befolyásának túlsúlyát mutató $\mathrm{HR}$ területek - vagy egyedül, vagy az ő dominanciájukkal meghozott döntések - a létszámváltoztatás és a bér-és juttatási döntések.

- E tekintetben azonban vizsgált mintáink szerint tapasztalhatók lényegi különbözőségek. Mindenütt a létszámnövelési vagy -csökkentési kérdés kapcsán a legmagasabb arányú a szervezeti vezetök önálló döntéshozatala. Azonban, amíg a magyar és a teljes mintában ez az arány szinte azonosan alakul (20-20\%), addig a kelet-európaiban a 30\%-ot is meghaladja. A fizetések és juttatási ügyek kapcsán még nagyobbra nő az eltérés a keleteurópai gyakorlatot illetóen. Miközben mind a magyar, mind a teljes minta válaszadói $19 \%$ körüli arányt jeleznek, a kizárólagos vezetői dominancia a kelet-európai mintában ennek már több mint a duplája (41\%).

- A munkaügyi kapcsolatok az a terület, ahol a HR szakemberek önállóan, a legnagyobb döntési felelösséggel müködnek. Ennek teljes mintabeli aránya meghaladja a 30\%-ot. A kelet-európai cégek válaszai ettöl jóval elmaradó $(15,2 \%)$, míg a magyar válaszok köztes, $27 \%$ körüli értéket mutatnak.

- A teljes mintában a HR-esek következő (14,8\% aránnyal) legfontosabb önállóan gyakorolt döntési területe a fizetések és juttatások. Mind a magyar, mind más kelet-európai kollégáik ettől lényegesen szerényebb (2,2\% ill. 8\%) arányban élveznek e területen autonómiát. Viszont némileg szabadabban döntenek a képzés-fejlesztési és a toborzás-kiválasztási ügyekben, mint a világ más részein praktizáló kollégáik.

- A kelet-európai mintáról elmondható, hogy minden vizsgált HR kérdésben magasabb vagy jóval magasabb a szervezeti vezetök felelösségi szintje, mint a teljes mintában. A magyar értékek majd mindenhol a teljes minta által jelzett gyakorlathoz állnak közel. 
3) A kutatás arra is igyekezett fényt deríteni, hogy amennyiben a válaszadó szervezet nagyobb vállalat vagy divíziócsoport része, akkor a HR kulcsterületeinek politikáját hol határozzák meg. A válaszokat szokásos mintáink szerint vizsgálva a következő tendenciák fogalmazhatók meg:

- Míg a teljes mintában nem teljesen azonos súllyal, de minden területen az országos központ befolyása a domináns, a kelet-európai országokban és köztük különösen a magyar válaszadók körében a helyi részlegek a teljes mintabeli társaikhoz képest jóval nagyobb önállóságot élveznek.

- A teljes minta határozottan központi - országos vagy nemzetközi - döntéseken alapuló területei a bérezés és juttatások, valamint a vezetöfejlesztés.

- A teljes mintában mintegy fele-fele arányban tartoznak a centralizált nemzetközi vagy országos -, központi döntésü, illetve a decentralizált - a leányvállalat vagy divizió, helyi részleg, iroda körébe utalt -, helyi döntésü HR területek kategóriájába a képzés-fejlesztés, a munkaügyi kapcsolatok és a létszám-változtatási ügyek.

- A helyi részlegek, hivatalok számára a legnagyobb önállóságot biztosító terület minden vizsgált mintánkban a toborzás, kiválasztás.

- Amennyiben létezik nemzetközi központ is, ott elsősorban a vezetésfejlesztési $(20 \%)$, a létszám-változtatási (14-20\%) és a bérezés, juttatási $(13 \%)$ politikát határozzák meg.

- A kelet-európai válaszadók - és benne különösen a magyarok - a teljes mintabelitöl szinte minden területen kisebb mértékü központtól való függést jeleznek.

- A magyar mintában föképpen az országos központ ereje mérsékelt. Döntési kompetenciájuk a teljes mintához képest jelentős mértékben divizionális vagy helyi szintre delegált. Mindezek eredményeként a központival szemben inkább helyiek befolyását jelzik olyan területeken, mint a képzésfejlesztés, a munkaügyi kapcsolatok, sőt még a bér és juttatási ügyek is.

- A nemzetközi központ által legerősebben kézben tartott HR funkció a magyar mintában a vezetöfejlesztés. Ezt a területet a többi mintában látható gyakorlathoz képest az országos központ sokkal kevésbé tartja kézben.

4) A CRANET-kutatás súlyponti kérdésköreinek megfelelöen, a kutatảsi eredmények valamennyi (korábbi és jelenlegi) mintában az emberi erőforrás menedzselés kulcsfunkcióihoz kötődnek. Ezek közül számos (mint a vállalati képzés és személyzetfejlesztés, a kiválasztás a termelékeny dolgozók kiszürése érdekében a felvételkor, a teljesítménymérés és -értékelés, a teljesítményfüggő javadalmazás és bérezés, a HR információs rendszerek múködtetése a dolgozók bevonása és tájékoztatása céljából) nemcsak a vállalati vezetőket és a szervezetkutatókat érdeklik, hanem a mikro-ökonómiai alapú humánerőforrás megközelítések tárgyát is képezik. A CRANET-kérdőív alapvetöen a korábban említett „mi van” típusú elemzésekre koncentrál, és itt ad a gyakorló menedzserek 
Farkas Ferenc - Karoliny Mártonné - Poór József :

Regionális különbségek az emberi erőforrás menedzselés gyakorlatában.

Tér és Társadalom 22. évf. 2008/2. 103-122. p.

számára értelmezhető (esetleg követhető) megoldástípusokat. A továbbiakban a kutatás empirikus eredményei közül csupán azokkal foglalkozunk, amelyek:

- a menedzsmenttudomány és gyakorlat múvelöinél szélesebb körü érdeklődésre is számot tarthatnak;

- regionális különbségeket mutatnak;

- és a vállalati mintasokaságokon belül statisztikailag igazolhatóak.

a) A kiválasztás során jellemzően alkalmazott, illetve mellőzött módszerek, technikák (4. táblázat) elemzése további sajảtosságok megfigyelésére adott alkalmat.

\section{TÁBLÁZAT}

A vezetök, a szakalkalmazottak és a fizikaiak körében használatos kiválasztási módszerek alkalmazásának aránya a magyar, a kelet-európai és a teljes felmérésben részt vevö szervezeteknél (\%)

(Percentage of Used Selection Methods among Managers, Specialists and Manual Workers within Organisations Participating in Hungarian, East European and the Whole Survey [\%])

\begin{tabular}{|c|c|c|c|c|c|c|c|c|c|}
\hline \multirow{3}{*}{$\begin{array}{l}\text { Kiválasz- } \\
\text { tási tech- } \\
\quad \text { nikák }\end{array}$} & \multicolumn{3}{|c|}{ Vezetők } & \multicolumn{3}{|c|}{ Szakalkalmazottak } & \multicolumn{3}{|c|}{ Fizikaiak } \\
\hline & \multicolumn{3}{|c|}{ Ország(ok) } & \multicolumn{3}{|c|}{ Ország(ok) } & \multicolumn{3}{|c|}{ Ország(ok) } \\
\hline & $\begin{array}{l}\text { Ma- } \\
\text { gyar }\end{array}$ & $\begin{array}{l}\text { kelet- } \\
\text { eu- } \\
\text { rópai }\end{array}$ & $\begin{array}{l}\ddot{O}_{s z-} \\
\text { szes }\end{array}$ & $\begin{array}{l}\text { Ma- } \\
\text { gyar }\end{array}$ & $\begin{array}{c}\text { kelet- } \\
\text { eu- } \\
\text { rópai }\end{array}$ & $\begin{array}{l}\ddot{O}_{S z-} \\
\text { szes }\end{array}$ & $\begin{array}{l}\text { Ma- } \\
\text { gyar }\end{array}$ & $\begin{array}{c}\text { kelet- } \\
\text { eu- } \\
\text { rópai }\end{array}$ & $\begin{array}{l}\ddot{O}_{s z-} \\
\text { szes }\end{array}$ \\
\hline $\begin{array}{l}\text { Panel } \\
\text { interjú }\end{array}$ & 70 & 48 & 61 & 64 & 41 & 50 & 31 & 17 & 25 \\
\hline $\begin{array}{l}\text { Interjú } \\
\text { (páros) }\end{array}$ & 52 & 57 & 56 & 41 & 64 & 60 & 38 & 51 & 54 \\
\hline $\begin{array}{l}\text { Jelentke- } \\
\text { zési lap }\end{array}$ & 19 & 30 & 43 & 19 & 37 & 49 & 19 & 40 & 47 \\
\hline $\begin{array}{l}\text { Pszichol. } \\
\text { teszt }\end{array}$ & 25 & 25 & 35 & 20 & 19 & 25 & 8 & 6 & 8 \\
\hline $\begin{array}{l}\text { Értékelő } \\
\text { közp. }\end{array}$ & 11 & 12 & 19 & 5 & 6 & 10 & 0 & 1 & 2 \\
\hline Grafológia & 14 & 3 & 4 & 6 & 3 & 2 & 1 & 1 & 1 \\
\hline $\begin{array}{l}\text { Referen- } \\
\text { ciák }\end{array}$ & 42 & 46 & 61 & 29 & 43 & 58 & 8 & 24 & 40 \\
\hline
\end{tabular}

Forrás: CRANET-kutatás (2005).

- Minden adat a vezetỏk kiválasztására fordított figyelem hangsúlyos voltát bizonyítja. Látszik ez egyrészt abból, hogy bizonyos módszereket (pl. értékelő központ) elsősorban e körben alkalmaznak, másrészt pedig abból, hogy itt a kiválasztási döntések megalapozása egyidejúleg többféle technika eredményének figyelembevételével történik.

- Az adatok tanulsága szerint a fizikaiak kiválasztási döntései képezik a fontossági skála másik szélső értékét. Őket jellemzően az egyszerübb, olcsóbb módszerekkel választják ki. 
b) A foglalkoztatási formák és az alkalmazott munkarend magyar mintájának elemzése során néhány érdekes összefüggésre bukkantunk. Az egyik szerint a túlóra alkalmazása összefüggést mutat (a korreláció értéke 0,216) a foglalkoztatottak számának változásával. Az eredményeink azt mutatják, hogy minél nagyobb százalékban alkalmazza a vállalat a túlórát, annál jellemzőbb, hogy létszám tekintetében is növekvő vállalatról van szó, $\mathrm{s}$ viszont: a növekvő vállalatok több mint egynegyedénél érinti a túlóra az alkalmazottak több, mint $50 \%$-át. Tehát a növekvő kapacitásigény egyszerre jelentkezik túlórákban és a dolgozói létszám emelkedésében.

Egy másik lényeges összefüggés alapján megállapítható, hogy a vizsgált rugalmas foglalkoztatási formák, megoldások - hétvégi munka, többmüszakos munka, túlóra, éves munkaóra szerződés, részmunkaidő, munkakör-megosztás, rugalmas munkaidő, ideiglenes/alkalmi munka, határozott idejü szerződések, otthoni munkavégzés, távmunka, sủrített munkahét - széles körü alkalmazása nem tünik túlzottan „kifizetỏdőnek". A magukat a felső eredményességi kategóriákba soroló mintabeli vállalatok ugyanis legfeljebb 5\%-ban alkalmazzák azokat.

Az alulról felfelé történó értékelés gyakorlata - amikor tehát a beosztottak is szerepet kaphatnak az értékelök között - a magyar és a globális mintában a válaszadók hasonló körében érvényesül (20\%), míg más kelet-európai szervezeteknél alig ( $10 \%$ alatt).

A munkatársak, mint értékelők bevonása a teljes mintában korlátozottan $(20 \%)$ érvényesülő gyakorlatnak tekinthetö. A magyar mintában ettől erőteljesebb $(26 \%)$, a kelet-európaiban gyengébb (15\%) e kör értékelői szerepe.

Végezetuil még egy meglepő azonosságról számolhatunk be. Eszerint az értékelésben betöltött legjelentéktelenebb szerep minden vizsgált mintában a vevőké, a külsö ügyfeleké.

A magyar vállalatok körében elvégzett kiegészítő vizsgálataink azt mutatják, hogy az önértékelés alkalmazása jellemzően a külföldi tulajdonú cégeknél történik, (79\%-uk jelezte ezt), míg a hazai tulajdonú vállalatoknál ugyanez az arány csak $40 \%$.

c) Ahogyan azt az 5. táblázat mutatja - a magyar minta kivételével - a képzés, emberi erőforrás fejlesztés területét tekintve azon válaszolók részaránya a legmagasabb, amelyek képzési költséghányada százalékban alig-alig kifejezhetően kevés. E szervezetek aránya a kelet-európai mintában a legmagasabb (41\%). Ha együttesen vizsgáljuk azon szervezeteket, amelyek éves munkabérköltségüknek maximum $2 \%$-át költik képzésre, azt láthatjuk, hogy a magyar és a teljes mintabeli súlyuk $55 \%$ körüli, míg a kelet-európaiaké a $60 \%$-ot is eléri. Igen magas tehát azon szervezetek aránya, ahol relatíve nagyon keveset fordítanak a személyzetfejlesztésre. 
Farkas Ferenc - Karoliny Mártonné - Poór József :

Regionális különbségek az emberi erőforrás menedzselés gyakorlatában.

Tér és Társadalom 22. évf. 2008/2. 103-122. p.

TÉT XXII. évf. 2008 - 2

Gyors ténykép

\section{TÁBLÁZAT}

A képzési költségek éves bérköltséghez viszonyitott aránya a magyar, a keleteurópai és a teljes felmérésben részt vevö szervezeteknél

(Rate of Training Costs to Annual Labour Cost within Organisations Participating in Hungarian, East European and the Whole Survey)

\begin{tabular}{cccc}
\hline Költséghányad (\%) & \multicolumn{3}{c}{ Ország(ok) } \\
\cline { 2 - 4 } & Magyar & kelet-európai & összes \\
\hline $0-1$ & 24 & 41 & 31 \\
$1,01-2$ & 30 & 19 & 25 \\
$2,01-4$ & 28 & 18 & 20 \\
$4,01-6$ & 11 & 10 & 14 \\
$6,01-$ & 7 & 12 & 11 \\
\hline
\end{tabular}

Forrás: CRANET-kutatás (2005).

A képzési költséghányad vizsgált három mintánkban érvényesülö átlagmutatói közül a magyar adat $(3,5 \%)$ a legmagasabb, bár nem sokkal haladja meg a teljes minta átlagértékét, ami 3,4\%. A kelet-európai mintában szereplỏ szervezetek csupán az éves bérköltségüknek átlagosan 3,2\%-át költik képzésre.

Mindhárom mintában a belső képzés tekinthető tipikusnak, hiszen míg ilyenben a munkatársak majd fele részesül, addig külső képzésben már alig több mint ötödük vesz részt.

d) A javadalmazás és ösztönzés területei között, az alapbér-meghatározás szintjeire a válaszok alapján megfogalmazható tendenciák a vezetőkre és a fizikaiakra vonatkozóan a 6. táblázatban szereplő adatokból nyomon követhetők. A szak- és az adminisztratív alkalmazottak körében érvényesülö sajátosságokat ezekhez viszonyítva vázoljuk.

Az alapbér-megállapítás jellemző szintjeit illetően a négy személyzeti kategóriában vizsgált mintáinkban markáns sajátosságok és eltérések azonosíthatók:

- A vezetök körében elsősorban egyéni, másodsorban pedig vállalati, ill. divízió szinten történik az alapbér-megállapítás. Mintáink adatai e területen csupán elhanyagolható különbségeket mutatnak.

- A 32 országot reprezentáló teljes mintában a fizikaiaknál a domináns országos vagy ágazati kollektív alku mellett, után kap szerepet a vállalati szintü bérmegállapítás. A 6. táblázat adatai szerint e téren a kelet-európai és föként a magyar gyakorlat lényeges eltérést mutat. Egyrészt a vállalati vagy divízió szintủ bérmeghatározás szerepe az elsődleges, másrészt a helyi részlegek szintjén történő megállapodások mellett az egyénieké sem elhanyagolható. „Köszönhetö" mindez annak, hogy a szakszervezetek és az általuk elért meg- 
állapodások regionális, ágazati és országos szinten egyaránt igen-igen korlátozott szerepet játszanak.

- A szak- és adminisztratív alkalmazottak körében a teljes minta országait illetően majd azonos arányban van jelen az eddig említett három - egyéni, vállalati és országos/ágazati alku - bér-megállapitási szint, ill. forma. A keleteurópai és föként a magyar szakszervezetek e körben játszott szerepének gyengeségét tükrözi, hogy miközben az országos vagy ágazati alkuk súlya a teljes mintában $30 \%$, addig a kelet-európaiban $20 \%$, a magyarban pedig csupán $10 \%$ körüli. Ennek eredményeként a bérmegállapítás jellemző szintjei és azok rangsora - vállalat/divízió, helyi részleg, egyéni - is eltér a teljes mintában érvényesülö, fent vázolt tendenciákétól.

\section{TÁBLÁZAT}

Az alapbér-megállapitás szintjeinek érvényesülése (\%) vezetôi és fizikai munkaköri kategóriákban a magyar, a kelet-európai és a teljes felmérésben részt vevö szervezeteknél (Rate of Training Costs to Annual Labour Cost within Organisations Participating in Hungarian, East European and the Whole Survey)

\begin{tabular}{lcccccc}
\hline \multirow{2}{*}{ Szintek } & \multicolumn{3}{c}{ Vezetók } & \multicolumn{3}{c}{ Fizikaiak } \\
\cline { 2 - 7 } & \multicolumn{3}{c}{ Ország(ok) } & \multicolumn{4}{c}{ Ország(ok) } \\
\cline { 2 - 7 } & $\begin{array}{c}\text { kelet- } \\
\text { európai }\end{array}$ & összes & Magyar & $\begin{array}{c}\text { kelet- } \\
\text { európai }\end{array}$ & összes \\
\hline $\begin{array}{l}\text { Orszá- } \\
\text { gos/ágazati } \\
\text { kollektív alku }\end{array}$ & 8,2 & 17,4 & 22,6 & 9,3 & 21,9 & 37,9 \\
$\begin{array}{l}\text { Regionális } \\
\text { kollektív alku }\end{array}$ & 3,1 & 6,6 & 5,8 & 4,1 & 11,9 & 14,6 \\
$\begin{array}{l}\text { Válla- } \\
\text { latDivízió }\end{array}$ & 39,2 & 35,2 & 35,1 & 38,1 & 30,8 & 25,2 \\
$\begin{array}{l}\text { Helyi részleg } \\
\text { Egyéni }\end{array}$ & 20,6 & 11,7 & 17,8 & 25,8 & 23,1 & 16,9 \\
\hline
\end{tabular}

Forrás: CRANET-kutatás (2005).

- Mindezek alapján megállapítható, hogy a helyi részlegek szintjén meghatározott alapbér a teljes mintában érvényesülönél jóval eróteljesebb szerepet játszik a kelet-európai, azon belül is föként a magyar mintában.

- A regionális kollektív alku - mint alapbér-meghatározási szint, ill. mód - minden vizsgált minta minden alcsoportjában az utolsó helyen szerepel. A vezetők esetében gyakorlatilag elhanyagolható a jelentősége. A többi alkalmazotti csoport esetében a teljes és a kelet-európai mintában tapasztalt 10\%-ot meghaladó súlya viszont már nem tekinthető lényegtelennek. 
Farkas Ferenc - Karoliny Mártonné - Poór József :

Regionális különbségek az emberi erőforrás menedzselés gyakorlatában.

Tér és Társadalom 22. évf. 2008/2. 103-122. p.

TÉT XXII. évf. 2008 — 2

Gyors ténykép

A pénzügyi participáció legszélesebb körben alkalmazott formája minden alkalmazotti körben a nyereségrészesedés.

Érintettjei leginkább a vezetők, majd csökkenő arányban a szak- (20\%) és az adminisztratív alkalmazottak (17\%) és a fizikaiak (14 \%). A vizsgált országcsoportok szerinti minták az adminisztrativ és a fizikai dolgozók kơrében egyaránt ezt a tendenciát követik. A teljes mintabeli alkalmazási gyakoriságot kissé alulmúlja a kelet-európaié és lényegesen a magyar.

- A dolgozói részvény meglehetősen szük kört érint, ám alkalmazása tekintetében a teljes minta cégeihez képest a kelet-európaiak némileg fölényben vannak.

- A részvényopció a teljes felmérésben részt vevő vállalatok vezetőinek mintegy $15 \%$-át érinti. A magyar minta szervezeteinek válaszai alapján kiegészítésként megállapítható, hogy a külföldi tulajdonúak meglehetősen magas $(43 \%)$, míg a magyar tulajdonúak jóval alacsonyabb $(10 \%)$ arányban kínálnak részvényopciót a menedzsment tagjai számára.

e) Vizsgálatunk adatai szerint a magyar minta cégei körében a legmagasabb $(34,7 \%)$ a nem szervezett dolgozókat foglalkoztató szervezetek aránya, és a legalacsonyabb $(6,3 \%)$ azon cégeké, melyekben az alkalmazottak 3/4-ét meghaladja a szakszervezeti tagok számaránya.

A többi kelet-európai országban - Szlovénia kivételével - a kizárólag nem szervezett tagokat foglalkoztató szervezetek mintabeli aránya a magyaréhoz hasonlóan magas, és lényegesen (több mint 10 százalékponttal) meghaladja a többi részt vevő ország ilyen adatait. A kelet-európai országok e jellemzői így az USA-beli és a kanadai cégek gyakorlatával mutatnak hasonlóságot, ahol szintén igen magas a nem szervezett dolgozókkal müködö cégek aránya.

A világ különböző régióiban foglalkoztatottak szervezettségének mértéke a hagyományok, a jogi és a politikai intézményi rendszer és a szakszervezetek fejlettsége alapján mindig mutatott eltéréseket. Mára világtendenciaként szerepük visszaszorulása érzékelhető. A korábbi szocialista országok valamikori kvázi 100\%-os szervezettsége olyannyira a múlté, hogy - legalábbis a mintabeli szervezetek esetében - a magas, 3/4-es szervezettségi szintet meghaladó szakszervezeti tagsággal müködő szervezetek aránya a teljes mintában jóval nagyobb ( $20 \%$-ot meghaladó), mint a keleteurópai szervezetek (10\%) esetében, köztük is különösen Magyarországon (6,3\%).

A magyar szakszervezetek kivételes gyengeségét az is mutatja, hogy az országos és /vagy ágazati szintü kollektív alkuk alapbér meghatározásban betöltött szerepe minden munkaköri kategóriában elenyészö.

\section{Összefoglaló megállapitások az azonosságokról és a különbségekról}

- A CRANET felmérés eredményei alapján megerösítve érezzük azokat a korábbi kutatási tapasztalatainkat, (Poór-Karoliny-Héjja 1998; Karoliny-Poór 2005a; 2005b; Karoliny 2006; Kiss-Poór-Gross-Javalgi-Solymossy 2006), 
amelyek azt mutatták, hogy a magyar vállalatok HRM-jében lezajlott $a$,,rendszerváltás".

- Az ebben a tanulmányban bemutatott összehasonlító vizsgálatok alapján azt is megállapíthatjuk, hogy a közép- és kelet-európai, volt szocialista országok valamikor igen hasonló $H R$ gyakorlatában szintén lényeges, de nem mindenhol azonos irányú és mértékü változások következtek be. A magyarországi változások sok tekintetben gyorsabbnak tủnnek, mint a kelet-európai régió más országaiban bekövetkezettek.

A CRANET-kutatás tapasztalatai szerint a HR funkció jelentőségét, illetve a HR részleg szerepét érintỏ magyar sajátosságok, amelyek eltérnek mind a kelet-európai, mind a teljes minta átlagértékeitől nem számottevőek, ám mégis értékelhetöek:

- Az egyébként is női dominanciájú $H R$ terület legeröteljesebben a magyar mintában bizonyult női szakmának.

- Amennyiben a szervezet nagyobb vállalat vagy divíziócsoport része, a HR terület kulcspolitikáinak meghatározói között az országos központ gyengébb befolyással rendelkezik. Így a helyiek befolyása eröteljesebben érvényesül, melynek fö területei: a képzés-fejlesztés, a munkaügyi kapcsolatok, sőt még a bérügyek is. Nemzetközi központ léte esetén annak fö befolyásterülete a vezetöfejlesztés. (Hasonló megállapításra jutottak német kutatók ([Roethling et al 2005]).

A HR funkció jelentőségét, illetve a HR részleg szerepét érintő magyar sajátosságok, amelyek más kelet-európai országokéval mutatnak hasonlóságot, a következök:

- A személyzeti költséghányad meglehetősen alacsony (40\% alatti) értéket képvisel.

- Nagyvállalat esetén a helyi részlegek HR politikát befolyásoló szerepe erös.

Végül a teljes minta átlagához közelebb álló magyar jellegzetességek:

- A magyar HR vezetó szervezeti stratégiakészitésbe bevontságának mértéke az összes ország felső harmadába helyezhetó el.

- A HR döntések minden funkciójában jellemző a megosztott felelösség, azaz a vezetők és a HR-esek együttdöntése. Ezek tipikus területei a toborzáskiválasztás és a létszám-változtatás. A tipikusan vezetöi túlsúlyos területek a létszámváltoztatás és a fizetések, juttatások.

- Összefüggés mutatkozik a személyzeti költséghányad és a szervezeti eredményesség között, miszerint - egy küszöbérték fölött - a magasabb bérköltséghányadú szervezetek alacsonyabb eredményességüek.

A HR funkció jelentőségét illetve a HR részleg szerepét érintő univerzálisnak minösíthető jellegzetességnek találtuk, hogy:

- a HR szakma női dominanciájú;

- az írott szervezeti stratégia és a HR stratégia szerepe meghatározó jelentőségü;

- a HR döntések tipikusan megosztott felelösségüek, melyben a HR szakemberek túlsúlya korlátozottan érvényesül; 
Farkas Ferenc - Karoliny Mártonné - Poór József :

Regionális különbségek az emberi eröforrás menedzselés gyakorlatában.

Tér és Társadalom 22. évf. 2008/2. 103-122. p.

- a HR munkát erőteljesen támogatják külső szolgáltatók, melyek szerepe a képzés-fejlesztés és a HR információs rendszerek területén meghatározó, és más funkciók esetében is növekvö.

Hasonlóképpen univerzális jellegü megoldásokat találtunk a kérdőives válaszokban a HR funkciók gyakorlásában. Ez a Mayrhoffer által többségi konvergenciának (Mayrhoffer-Reichel 2006) nevezett jelenség létére utal a vizsgált teljes mintában. Ez négy-öt markáns jellemzőt mutat a személyzetbiztosítás, a képzés-fejlesztés, a javadalmazás-ösztönzés, valamint az alkalmazotti kapcsolatok területén. A megoldások részletezése nélkül is megállapítható, hogy a HR döntéshozóinak és alkalmazóinak gondolkodását és viselkedését a pragmatikus megközelítések uralják. Az emberi erőforrás menedzserek napi munkájukban a „mit?" és „hogyan?” kérdéseire koncentrálnak, és a költség/haszon relációk elemzésére irányuló „miért?” típusú kérdésekkel való törődést meghagyják a vállalati vezetőknek és a tulajdonosoknak.

\section{Jegyzet}

${ }^{1}$ A tanulmány az K62169 sz. OTKA pályázat támogatásával késziult. Az adatok feldolgozása SPSS programesomag felhasználásával történt, a feldolgozásban közremüködött Kiss Tibor egyetemi docens és Hadinger Britta PhD hallgató (PTE KTK).

\section{Irodalom}

Alas, R.-Svetlik, I. (2004) Estonia and Slovenia: Building Modern HRM Using a DualistApproach. Brewster, C.-Mayrhofer, W.-Morley, M. (eds.) Human Resource Management in Europe Evidence of Convergence? Elsevier, London. 353-385. o.

Anthony, P.-Crichton, A. (1969) Industrial Relations and the Personnel Specialist. Batsford, London.

Brewster, C.-Mayrhofer, W.-Morley, M. (eds.) (2004) Human Resource Management in Europe Evidence of Convergence? Elsevier, London.

Brewster, C.-Wood, G.-Brookes, M.-Van Ommeren, J. (2006) What Determines the Size of the HR Function? A Cross National Analysis. - Human Resource Management. 45. 3-21. o.

Budhwar, P.S.-Sparrow, P.R. (2002) An integrative framework for understanding cross-national human resource management practices. - Human Resource Management Review. 12. 377-403. o.

CRANET (2006) International Executive Report 2005. Cranet Survey on Comparative Human Resource Management. Cranet-Cranfield University, Cranfield.

Ehrenbeg, R.G.-Smith, R. (2003) Korszerü munkagazdaságtan. Panem Könyvkiadó, Budapest.

Elbert, N.F.-Karoliny M-né-Farkas F.-Poór J. (1994) Személyzeti/emberi eröforrás menedzsment kézikönyv. Közgazdasági és Jogi Könyvkiadó, Budapest.

Evans, P.-Pucik, V.-Barsoux, J. (2002) The Global Challenge: Frameworks for International Human Resource Management. McGraw-Hill/Irwin, Homewood.

Farkas F.-Karoliny M-né-László Gy. (2003a) Diagnózis az emberi erőforrások menedzseléséről. I. Humánpolitikai Szemle. 10.3-19. o.

Farkas F.-Karoliny M-né-László Gy. (2003b) Diagnózis az emberi erőforrások menedzseléséről. II. Humánpolitikai Szemle. 11. 3-16. o.

Gooderham, P.-Morley, M.-Brewster, C.-Mayrhofer, W. (2004) Human Resource Management: A Universal Concept? - Brewster, C.-Mayrhofer, W.-Morley, M. (eds.) Human Resource Management in Europe: Evidence of Convergence? Elsevier, London, 417-436. 0.

Jackson, S.E.-Schuler, R.S. (1995) Understanding human resource management in the context of organizations and their environment. - Annual Review of Psychology. 46. 237-264. o.

Karoliny, M-né (2006) Pioneers on the HR Ground. Experiences from Hungary. EIASM 21 th Workshop on Strategic Human Resource Management. March 30-31. Aston Business School, Birmingham. 
Karoliny, M-né-Csetneki, Zs.-Poór, J.-Spisák, Gy. (2000) Human Resource Management Practices at Large Hungarian Private Companies. - Rekettye, G. (ed.) The Significance of the Last Decade. 176-193. o.

Karoliny M-né-Poór J. (szerk.) (2005) Emberi eröforrás menedzsment a közszolgálatban: Módszertani kézikönyv. Szókratész Külgazdasági Akadémia, Budapest.

Karoliny, M-né-Poór, J. (2005) Convergences and Divergences in Human Resource ManagementHungarian Perspectives. - „Nové trendy v podnikovom manažmente." Zbomik $\mathrm{z}$ mezdinárodnej konferencie. Szept. 13-14. Košické Hámre, SR. 108-120. o.

Kiss K.-Poór J. (2006) A kis- és közepes vállalkozások (KKV) menedzsment és HR sajátosságai magyarországi régiókban - az életciklus modell tủkrében. - Munkaügyi Szemle. 9. 14-19. o.

Kiss, K.-Poór, J.-Gross, A.-Javalgi, R.-Solymossy, E. (2006) Emerging Enterprises in Central Europe. (Conference proceeding) 20th Anniversary Meeting, The UIC Symposium on Marketing \& Entrepreneurship. August 2-4. University of Illinois at Chicago, Chicago, Illinois.

Koubek, J.-Vatckova, E. (2004) Bulgaria and Czech Republik: Countries in Transition. - Brewster, C.Mayrhofer, W.-Morley, M. (eds.) Human Resource Management in Europe Evidence of Convergence? Elsevier, London. 313-352. o.

Lazaer, E.P. (2003) Working Papers by NBER Working Group - PER. http://www.nber.org/workinggroups/per/per/html Letöltve: 2007 . május 12.

Lazaer, E.P. (2006) A humán eröforrások közgazdaságtana vállalati vezetök részére. Nemzeti Tankönyvkiadó, Budapest.

Locke, R.-Thelen, K. (1995) Apples and oranges revisited: contextualized comparisons and the study of comparative labor politics. - Politics and Society. 23. 337-367. o.

Mayrhofer, M.-A. Reichel (2006) Looking for the Holy Grail? Tracking human resource management developments over time-reflections on theoretical and methodological issues. 21st Strategic HRM workshop. March 30-31. Aston Business School, UK.

Mayrhofer, W.-Morley, M.-Brewster, C. (2004) Convergence, Statis, or Divergence? - Brewster, C.Maythofer, W.-Morley, M. (eds.) Human Resource Management in Europe: Evidence of Convergence? Elsevier, London. 417-436. o.

Poór J. (szerk.) (1996) Nemzetközi emberi eröforrás menedzsment. Közgazdasági és Jogi Könyvkiadó, Budapest.

Poór J. (2005) Rugalmas ösztönzés - rugalmas juttatások. KJK-Kerszöv, Budapest.

Poór J. (2006) HR mozgásban - nemzetköziesedés az emberi eröforrás menedzsmentben. MMPC, Budapest.

Poór J.-Farkas F. (2001) Nemzetközi menedzsment. Közgazdasági és Jogi Könyvkiadó, Budapest.

Poór, J.-Gross, A.-Farkas, F.-Roberson, M.-Karoliny, M-né-Susbauer, J (2007) Human Resource Management in Central Europe: Policies and Practices. International Business and Economy Conference (IBEC) Emerging Issues in the Global Economy. January 4-7. San Francisco.

Poór, J.-Karoliny, M-né-Héjja, L. (1998) Major Trends of Human Resource Management within Local and Foreign Owned Ventures in Hungary. Workshop on Strategic Human Resource Management. April 6-7. Brussels.

Poór, J.-Tódor, M. (2004) Labour Force Issues in Modern Hungary-a Survey of Employees in Advance of EU Accession. Research Insights. Mercer Human Resource Consulting. February. 3-6.

Roehling, M.V.-Boswell, W.R.-Caliguri, P.-Feldman, D.-Graham, M.E--Guthrie, J.P.-Morishima, M.Tansky, J.W. (2005) The Future of HR Management: Research Needs and Directions. - Human Resource Management. 2. 207-216. o.

Schuler, R.S.- Dowling, P.J.-De Cieri, H. (1993) An integrative framework of strategic international human resource management. - The International Journal of Human Resource Management. 4. 717-764. 0.

Sparrow, P.-Hiltrop, J.M. (1994) European Human Resource Management in Transition. Prentice Hall, London.

Sparrow, P.-Hiltrop, J.M. (1998) Redefining the field of European human resource management. Mabey, C.-Salamon, G.-Storey, J. (eds.) Strategic Human Resource Management. Sage, London. 68-96. o.

Szöts-Kovács K. (2006) Merre tart az emberi erőforrás menedzsment? - Vezetéstudomány. Különszám. 46-55. o.

Tregasikis, O.-Mahoney, K.-Atterbury, S. (2004) Appendix 1-International Survey Methodology: Experiences from the Cranfield Network. - Brewster, C.-Mayrhofer, W.-Morley, M. (eds.) Human Resource Management in Europe: Evidence of Convergence? Elsevier, London. 437-450. o.

Vatchkova, E. (2005) Competence-based Human Resource Management Training. „HRM in a Knowledge Based Economy." June 2-4. Ljubljana.

Vatchkova, E.-Musztyné B.B.-Gyurkó Zs. (2006) Emberi erőforrás menedzsment helyzete és fejlódési tendenciái Bulgáriában. - Személyügyi Hirlevél. június. 3-11. o. 